\title{
食塩電解工業におりる高分子材料の應用 (I)
}
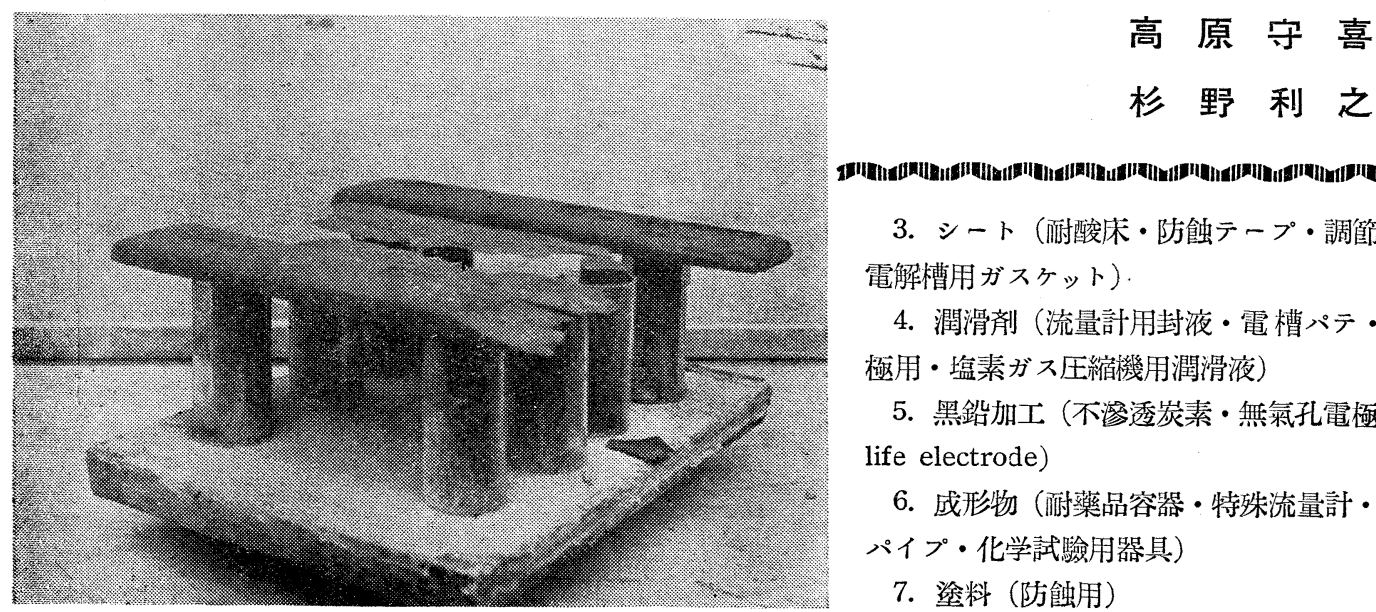

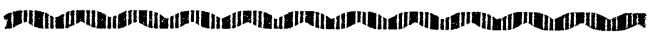

3. シート（耐酸床・防蝕テープ・調節電極用・ 電解槽用ガスケット)

4. 潤滑浏（流量計用封液・電槽パテ・調節電 極用・塩素ガス圧縮機用潤滑液 $)$

5. 黑鉛加工（不滲唀炭素・無氣孔電極一Long life electrode)

6. 成形物 (耐藥品容器・特殊流量計・ゲージ パイプ・化学試驗用器具)

7. 塗料（防蝕用）

竹中委員から揭題の內容について執筆せよとの御低賴 でめったが，さて改めて考えて見ると電解工業という範 儔（もっとも筆者らの経驗から食塩電解工業に限られる のであるが）では現在のところゴム以外には余り高分子 材料を駆使しているといらわけにはゆかず，ただ余りに 絢䦥たる高分子化合物の華にとまどいしつつ無限の期待 を將來にかけているという現狀である。從って問題を余 り定量的に記述できないのが抟念であるが，例えば筆者 ら無機関係技術者が 10 数年有機化学に遠ざかってその 序論さえ忘れかけていると同樣に久しく無機電解などに 遠ざかっていた会員も蛙られることを考えて，蛇足なが ら食塩電解工業の原理などをあわせ述べ高分子材料の應 用が考えられる部分について例を挙げて解說を試み，責 そふせぐことにしたい。

さてここに高分子材料の篧用を考えるときわれわれ食 塩電解の仕事はその分解生成物の 1 つである塩素まるい はその化合物による腐蝕との絕ゆることなき闕いである ことを今更のように感ずる次第で，このため自動制禦そ の他工場の近代化女阻ま机從業員の作業環境, 從って作 業能率子殆えど旧態依然たるものがありわれわれの高 分子材料への期待の大牛がこの点にかかっているといっ ても過言ではもるまいと思う。次に㫿用例の 2,3 学 げてみると次のようである。

1. 纎維（隔膜・沪布・作業衣）

2. ライニング（電解槽・榆送機械・貯槽・輸揆管）

カツト : Impregnation を行っを黑鉛霞極の水銀 法電解槽に扣ける崩壊 (昭和 14 年味の素川崎 工場に扣ける使用例 使用條件 $20 \mathrm{~A} / \mathrm{dm}^{2}$, 約 1 籄月使用, 通常の場合だと約 10 箇月の便用 涌预完る）(次号参照）
8. イオン交換樹脂（ソーダ製造用・䍄水及び解 手水 精製用)

以下この順に從って說明を進めて行くことにする。

1. 緎 維

(A) 電解隔膜 $1,2,3$,

精製した食塩飽和溶液を分解して目的の反應

$$
\mathrm{NaCl}+\mathrm{H}_{2} \mathrm{O}=\mathrm{NaOH}+\frac{1}{2} \mathrm{H}_{2}+\frac{1}{2} \mathrm{Cl}_{2}
$$

を行らために黑鉛陽極と鉄陰極で電流を通ずると容易に 上記 3 成分にわかれるが一旦分解した各成分は再び混合 して電解慒內に扔いて種々の副反應を惹起して能率が低 下するのでこれを防ぐため隔膜を用いる4)。いま液が流 動せず塩素ガス及び水素ガスも液殿を攪挥することなし に電解槽外江導かれると仮定すると

(1) 陽極面で $\mathrm{Cl}^{-}$が放電して $\mathrm{Cl}_{2}$ になり

$$
\mathrm{Cl}^{-}+\oplus \longrightarrow \mathrm{Cl} \longrightarrow \frac{1}{2} \mathrm{Cl}_{2}
$$

（2）陰極周国の食塩水は塩素にて飽和して加水分解に より微酸性を呈し次亞塩素酸を生ずる

$$
\mathrm{Cl}_{2}+\mathrm{H}_{2} \mathrm{O} \longrightarrow \mathrm{H}^{+}+\mathrm{Cl}^{-}+\mathrm{HClO}
$$

(3)いしかるにさらに電解が進行するとともに陰極に生 じた $\mathrm{OH}^{-}$は陽極に向うて移動してまず塩酸を中和する

$$
\mathrm{Cl}_{2}+\mathrm{NaOH} \longrightarrow \mathrm{NaCl}+\mathrm{HClO}
$$

（4）さらに陰極に近づくに從い $\mathrm{OH}^{-}$が多量に侵入し て $\mathrm{HClO}$ むまた中和せられる

$$
\mathrm{Cl}_{2}+2 \mathrm{NaOH} \longrightarrow \mathrm{NaCl}+\mathrm{NaOCl}+\mathrm{H}_{2} \mathrm{O}
$$

(5) 陰極面に $\mathrm{Na}^{+}$が放電し水と作用して $\mathrm{NaOH}$ と $\mathrm{H}_{2}$ を生ずる

$$
\mathrm{Na}^{+}+\Theta+\mathrm{H}_{2} \mathrm{O} \rightarrow \mathrm{NaOH}+\mathrm{H} \rightarrow \mathrm{NaOH}+\frac{1}{2} \mathrm{H}_{2}
$$




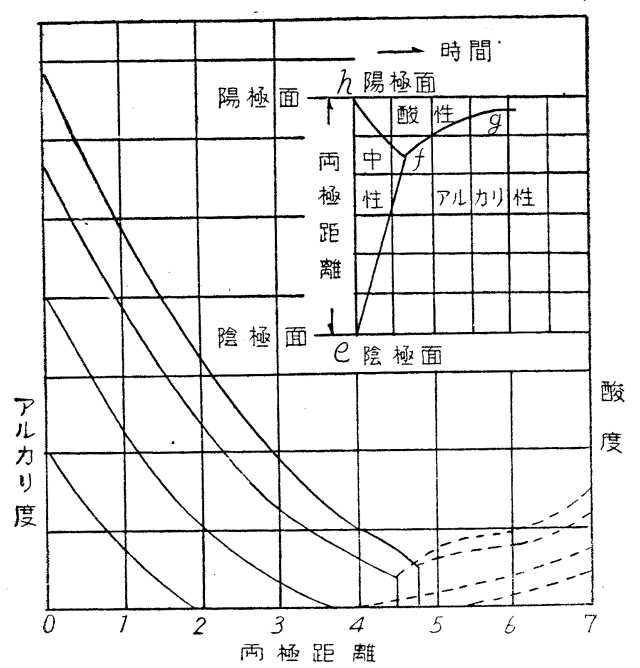

第 1 圖

以上の反隹を図示すると第 1 図のごとくなって gに至る がこのとき液曆を縱断してその成分を檢べると第 1 表の ごとくになっている。

第 1 表

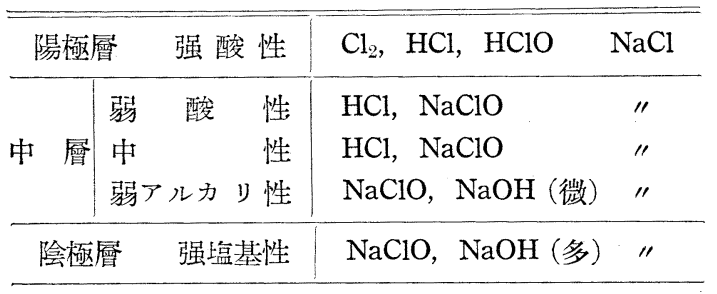

もしこのままこの淮行に委しておけばアルカリ層はつい に陽極にまで到達するので隔膜を用いて中性層の位置を 一定に留めて和く, 上記は電解槽內部の原則的な場合で あるが何等の原因で陽極に向って $\mathrm{OH}^{-}$の暴狀侵入が起 ると次の副反隹を生ずる。

(6) 上記 (4) (5)の間にさらに反應を起して塩素酸》 ーダを生ずる。

$$
\begin{aligned}
& 2 \mathrm{HClO}+\mathrm{NaClO} \longrightarrow \mathrm{NaClO}_{3}+2 \mathrm{HCl} \\
& 2 \mathrm{HCl}+2 \mathrm{NaClO} \longrightarrow 2 \mathrm{NaCl}+2 \mathrm{HClO}
\end{aligned}
$$

$$
3 \mathrm{NaClO} \longrightarrow \mathrm{NaClO}_{3}+2 \mathrm{NaCl}
$$

(7) さらに $\mathrm{OH}^{-}$の侵入が增加し (5) の狀態が陽極面 に達すると $\mathrm{ClO}^{-}$が放電して塩素酸と酸素を生成する。

$$
6 \mathrm{ClO}^{-}+6 \oplus+3 \mathrm{H}_{2} \mathrm{O} \longrightarrow 2 \mathrm{ClO}_{3}+4 \mathrm{Cl}^{-}
$$$$
+\frac{3}{2} \mathrm{O}_{2}+6 \mathrm{H}^{+}
$$

(8) $\mathrm{OH}^{-}$の侵入がさらに甚しくなると陽極液はつい にアルカリ性となり $\mathrm{OH}^{-}$が直接放電して酸素を発生し $\mathrm{Cl}_{2}$ の收量激減する。

$$
2 \mathrm{OH}^{-}+\oplus \longrightarrow \mathrm{H}_{2} \mathrm{O}+\mathrm{O} \longrightarrow \mathrm{H}_{2} \mathrm{O}+\frac{1}{2} \mathrm{O}_{2}
$$

（9）また食塩水中の $\mathrm{SO}_{4}=$ は電流を運えで陽極に集ま り漸次蓄積し一方電解の進捗に從って食塩濃度減少しつ
いに $\mathrm{SO}_{4}=$ が放電して酸素を発生する。

$$
\mathrm{SO}_{4}=+2(+)+\mathrm{H}_{2} \mathrm{O} \longrightarrow \mathrm{H}_{2} \mathrm{SO}_{4}+\frac{1}{2} \mathrm{O}_{2}
$$

以上が電解槽內で起る反礁の大略であるがこれによって 隔膜に接触するイオン群を知ることができるわけです る。しかして陰極を通過して得られる陰極液の組成の 1 例を次に示す。

第 2 表

\begin{tabular}{|lc|ll|}
\hline $\mathrm{NaCl}$ & $180 \mathrm{~g} / 1$ & $\mathrm{Na}_{2} \mathrm{SO}_{4}$ & $7.7 \mathrm{~g} / 1$ \\
\hline $\mathrm{NaOH}$ & $120 \mathrm{~g} / 1$ & $\mathrm{Fe}_{2} \mathrm{O}_{3}$ & $0.01 \mathrm{~g} / 1$ \\
\hline $\mathrm{NaClO}_{3}$ & $0.09 \mathrm{~g} / 1$ & $\mathrm{Na}_{2} \mathrm{SiO}_{3}$ & $0.05 \mathrm{~g} / \mathrm{l}$ \\
\hline $\mathrm{NaClO}$ & 痕跡 & & \\
\hline
\end{tabular}

実際に食盐電解に用いられる隔膜には密隔膜と沃隔膜と がある。前者は電解液の通過を妨げてイオンの久が通過 する密な隔膜であり後者は一定の水位の差で電解液を通 過さす隔膜である。現在はるっぼら佩隔膜により陽極室 より陰極室に食塩水を流して連続的に操業している。材 質としては後述の性質を具備することが必要であるが大 体上記の通り $15 \%$ 位の食塩含有苛性ソーダ陰極液と塩 素を含む食塩陽極液に耐えねばならず溫度は 60 〜 $70^{\circ} \mathrm{C}$ 位になる堅型隔膜法ではアスベスト紙を重ねて張り, 水 平型の場合はアスベスト布を敷きその目つめに $\mathrm{BaSO}_{4}$, 石綿繊維を用いて透過率を加減する。Hooker の古、特 許では石綿布の上に $\mathrm{Fe}_{2} \mathrm{O}_{3}$, 石綿繊維, コロイド狀水酸 化鉄混合の泥狀物を陰極面に叙布したものを用いてお $\eta^{5,6)}$, 最近のものは長纎維の石綿を水中に䀣濁させて 牤き陰極となる鉄金網上に臭空沪過式で張りつめる(こ れ deposited diaphragm といら)これらの石綿紙, 布 は殆んど全部が輸入であって最近電氣化学協会電解隔膜 委員会などでも國產石綿隔膜を研究しているが7, 40) 末 だ完全に満足なるのは得られないようである。隔膜はか ようにもっぱら石綿が用いられるが，さりとて石綿でな

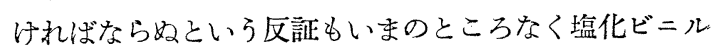
その他の材料も考えられるわけで岁る。だ゙現在は戰時 中の隔膜拂底に慌てて代用隔膜として試驗をはじめた程 の熱意もなくさしあたり安易について石綿に依存しおり そこになんの進步はもちろん研究意照子存在しないかに 見える。しかし原料石綿特に高級石綿原料の輸入は非常 に困難で情勢の变化によっては輸入にの及依存すること は心細い限りである。カナダ石綿生產の約 80〜90\% を 買付けつつある米國に和いてさえ昭和 27 年 1 月 17 日 附で米國々防生產局より原料石綿の使用制限が公布され ている現狀である ${ }^{41) 。}$

さてかくのごとく沪隔膜は陽極室より陰極室へ食塩水 を連続的に流して使用するからその効果は輸率によるも のの寄與は少く $\mathrm{OH}^{-}$の拡散之両極生成物の混合を防止 
しているのである。このためできるだけ目が細かいこと が望ましいが目が細かいことほ逆にこれによる電氣抵抗 の增加を意味するので適当な孔の大きさを定めこれに應 じた流速によって中性曆の位置を定めるようにする。往 時より Förster ${ }^{8}$, Hooker ${ }^{9}$ によより完全隔膜 (Perfectdiaphragm) ということがいわれているが，向坊氏は次 のごとく定義づけている。すなわち理想的には電氣抵抗 が0でイオン通過に対し選択性を持ち例えば食塩電解に 特いては流れの方向には $\mathrm{Na}^{+}$のみを通して $\mathrm{H}^{+}$を通さ ず逆の方向には $\mathrm{Cl}^{-}$の夕を通して $\mathrm{OH}^{-}$を通さないよう な隔膜であるが，後者はなかなか実現困難であるから暫 く措けば結局電流効杽が最高であるような最適流量のと き電氣抵抗を有しないような隔膜であるというのであ

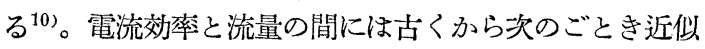
式があって電流効率 $P$ が最大になるような流量 $V m$ の 值が存在する11)。ここに $\mathrm{NoH}$ は $\mathrm{NaOH}$ の損失量, $I$ は 電流の大きさ, $\mathrm{Co}_{\mathrm{H}}$ は隔膜內の中性層のアルカリ側の $\mathrm{NaOH}$ の濃度である。

$$
\rho=1-\mathrm{NoH}_{\mathrm{H}}=1-\left(\frac{V m}{I}\right) \mathrm{CO}_{\mathrm{H}} \mathrm{Fr}
$$

向坊氏はさらに考察を進めて定常狀態に抢ける $\mathrm{Cl}_{2}, \mathrm{H}^{+}$ $\mathrm{OH}^{-}$の移動量について微分方程式をたてこれを解いて 次式を得た ${ }^{12)}$ 。

$$
\rho=100 \times\left\{1-\frac{\mathrm{C}^{\circ} \mathrm{OH}_{\mathrm{H}}}{\mathrm{i}} \frac{\mathrm{N}^{\circ} \mathrm{O}_{\mathrm{H}} \cdot \mathrm{i}-\mathrm{V}}{1-\exp \left[-\frac{\mathrm{N}^{\circ} \mathrm{O}_{\mathrm{H}} \cdot \mathrm{i}-\mathrm{V}}{\mathrm{KO}_{\mathrm{H}}^{-}}\left(d-d_{1}\right)\right]}\right\}
$$

ただし $\mathrm{C}^{\circ} \mathrm{OH}$ は $\mathrm{OH}^{-}$の陰極室における定常濃度, $\mathrm{NOH}^{-}$ は $\mathrm{OH}^{-}$の輸率を濃度に比例するという近似を用いたと きの比例常数, $V$ は流速, $1 d$ は隔膜の厚さ, $\mathrm{Ko}^{-}$は $\mathrm{OH}^{-}$の拡散常 数に隔膜の眞の面積の見脚面積に対する 比を脚けたものである。 $d_{1}$ は中性層の位置を酸側から測 った長さで計算によると殆んど0に等しい, 若干の補正 を施せば（14）式は実際の場合とよい一致を示す42。

次に隔膜の特性について述べよう。隔膜は上記のごと き分離を目的とするけれぞる液やイオンの通過する孔の 性質はその最々重要な特性であって化学的または機械的 な耐久性とともにその可否の鍵となるべきるのである。 その孔の性質をあらわすパラメーターとしては

1. 有孔度 (Porocity) ${ }^{18)}$

2. 透過六 (Permeability) ${ }^{13}, 14,16$ )

3. 孔の大きさ及び数 15,16 ,

4. 孔の長さ (隔膜の厚さとは異なる)

などがあるがその定義・測定法については記述の㗇がな いので詳細は交献を参照せられたい。隔膜を溶液に浸し たときの電氣抵抗 $\rho d$ 孔孔の性質を綜合した重要な性質 であるが, Stender は次式を提出している。

$$
\rho d=\frac{\rho \cdot d \cdot \alpha}{A q}
$$

ここに $\rho$ は電解夜の固有抵抗, $d$ ほ隔膜の厚さ, $\mathrm{A}$ は隔
膜の有効面積， $q$ ほ有孔度 $/ 100 ， a$ ほ電氣抵抗の実測值 が理論值 $(\rho d / A q)$ に対する比をあらわす值 ${ }^{14)}$ ，しかして $\alpha=2 \sim 3$ の值を示す $-1,2,15)$ ～$\alpha>1$ であることは隔膜の 孔が複亲な構造を持台曲りくねった毛管通路であること を示し a は通路の長さ/隔膜の厚さに等しい。 る電圧降下の值は 0.15 0.2 V であるという外あまり測 定值がないようである。次に先の 4 項の中最子重要な透 過率について少し触れて見ることにしょう。透過率は

$$
K=\frac{V d \eta}{S H T}
$$

で示される。ただし $K$ ほ絕対透過係数, 厚さ $d(\mathrm{~cm})$ を 時間 $T(\mathrm{~min})$ に静水圧 $H(\mathrm{~cm})$ により通過する流量を

\begin{tabular}{|c|c|c|c|}
\hline & & 実際電 & 掟值 \\
\hline 製 品 名 称 & 實 簽 室 & $40^{\circ} \mathrm{C}$ & $60^{\circ} \mathrm{C}$ \\
\hline Johns-mannville & 0.0087 & 0.0057 & 0.0042 \\
\hline Wattson & 0.0250 & 0.0180 & 0.0100 \\
\hline 國蓙試作品 (Na. 2) & 0.0080 & 0.0092 & 0.0084 \\
\hline
\end{tabular}

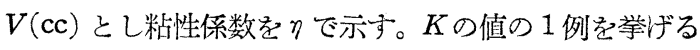
と第 3 表のごとくである7。

\section{第 3 表}

な持透過率深厚さ $1 \mathrm{~cm}$ のきの $\mathrm{cc} / \mathrm{hrdm}^{2}$ であらわす こともありその值は例えば通電值後 $17.65,300$ 時閒後 12.94 (Wattson の值) といった值である。

現在の隔膜の賱入規格の 1 例 (Allen-Moore KLM型) を挙げると第 4 表のごとくである门。

以上隔膜の特泩を示すパラメーターを說明したがもと ると電解の反雉機棈及び電解槽の化学工学には未だ不明 の点が少くなく, ことに隔膜については工場のデータに

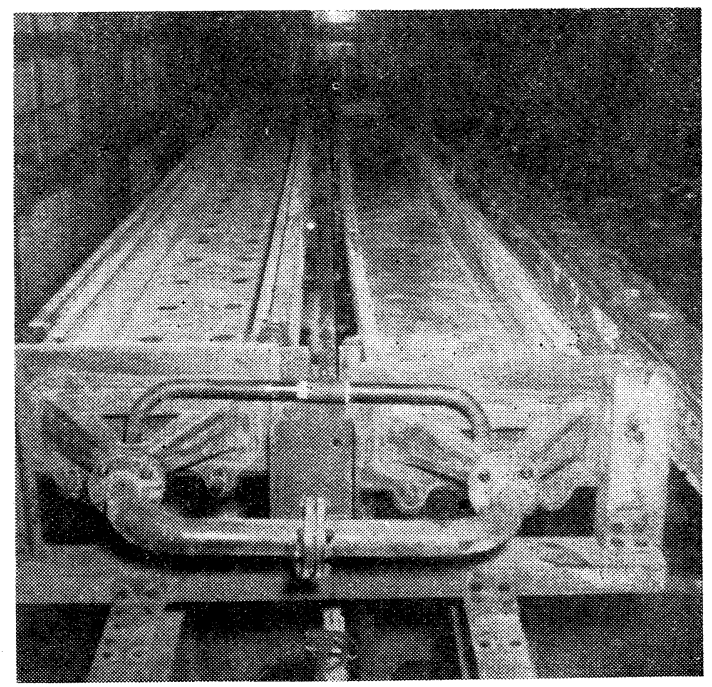

コンクリート製及び硬質ゴムライニング Krebs 式電解 槽(向って右がゴムライニング製, 黑鉿陽極を取り出して 底面を見せている。コンクリート槽の底面に点々と円形 部が見觉るのか除極，ての上を水銀が流れる） 


\section{第 4 表}

1. ピンホール 皆奥

2. 有孔度 $60 \%$ 前後

3. 見掛比重 $0.85 \sim 1.04 \mathrm{~g} / \mathrm{cm}^{3}$

4. 强度 常態 $50 \mathrm{~g} / \mathrm{mm}^{2}$ 以上, 液中 $2.5 \mathrm{hr}$ 後 $2 \mathrm{~g} / \mathrm{mm}^{2}$ 以上

5. 吸水率 (水中 $2.5 \mathrm{hr}$ 後) $250 \%$ 以下

6. 灼熱減量 $18 \%$ 以下

7. K (常溫水にて) $0.008 \sim 0.028$

8. 寸法 $20 \sim 25 \mathrm{mil} \times 1625 \times 2390 \mathrm{~mm}$

より経驗的にまた定性的に取り报われて來たことが多く 上記の規格にしてもどの位明確な理論または実驗的根拠 によっているか不明である。工場で用いられる数值には よくこういう数值があり，例えばわれわれが購入する電 解槽用黑鉛電極の品質規格がしかり，化瀻工場がわれわ れから購入される䛴性ソーダの要望規格にもそらいう項 目があるようである。隔膜についての上記諸量（例えば 孔の長さ）る未だ実驗室的研究の域を脫しないのであっ て旧態依然たる隔膜を改良してゆくには物理的・電氣化 学的・材料化学的乞して化学工学的に理論及び実驗的研 究が要請される。その 1 例として前揭した電氣化学協会 電解隔膜委員会があるが現在迄の発表では代用國崖紙の 製造による石綿の輸入防遏に目的を特いているようであ り高分子材料による成果は未だ発表していないし隔膜そ のものの学術的研究は横浜國立大学松野助敎授力漙心乙

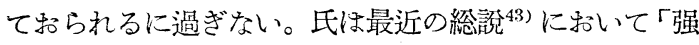
度などの点から合成高分子材料の進出が期待されるが経 済的な理由からか未だ工業的に使用されていないる述 ベておられる。

隔膜石綿は原單位苛性ソーダ $1 \mathrm{t}$ 当り布 $0.15 \mathrm{~kg}$, 紙 $1.00 \mathrm{~kg}$ 兩者とるで平均 $0.4 \mathrm{~kg}$ 位であり, 昭和 26 年度苛 性ソーダ生產約 8 万 $\mathrm{t}$, 隔膜の使用約 $35 \mathrm{t}$ であった ${ }^{17)}$ 。 これが全部代替されたとしても高分子材料（化繊）の生 產高から見れば九牛の一毛であるけれども要はソーダ工 業の合理化（能率的焉るいは原價的な）による貢献であ り，ひいては苛性ソーダ及び塩素の生産コストの引下げ にあるのである。しかし現実には隔膜に対する一般の関 心，なかんづく高分子材料隔膜への関心は比較的うすく 実驗例ば次の $1 ， 2$ に留まるようである8。

（イ）ゴム製品軟質ゴムは相当耐アルカリ性であ るか陽極液によって容易に侵されるので隔膜材料として 不十分である。硬質ゴムほある程度陽極夜にも耐えるが 彈力性に乏しいので不適当であろう。

(ロ）アルギン酸繊維東京工業試驗所の研究にな る謟瀻維は弱アルカリにはよいが强アルカリに侵される ので実用にならなかった。

（八）醀酸ビニル繊維、鐘紡製カネビアンはその耐 アルカリ性は相当大であったが陽極液により腐蝕され
10 数日にして殆えど跡を止めない程溶解された。

（二）塩化ビニル纎維 日空の堭化ビニル（塩化ビ ニル $85 \%$, 酶酸ビニル 15\%共重合物, 塩素含有量 $45 \%$ ) は耐アルカリ，耐陽極液ともに酢酸ビニルより良好であ るが軟化点低く約 $90^{\circ} \mathrm{C}$ の水, 食塩水, アルカリなどで 15 分処理したものは原形の $40 \%$ に收縮する。ハンカチー フ織の收縮したもの $1 \mathrm{~m}^{2}$ の重量は $0.4 \mathrm{~kg}$ で石綿の重量 に比し 1/4〜1/5 であった。これらは昭和 19 年上期に旭 電化株式会社に和いて試驗を行った結果は古いデーター なので詳細は省略するが十分実用に供し得るものと認め られた。また同時期に日衰化学株式会社王子工場で短瀻 維石綿に約 $10 \%$ 混入して $70^{\circ} \mathrm{C}$ 程度で約 1 籄月牛試驗 を行ったがその結論として「大体長纎維の代用として Hooker-S 型電解慒にほ使用し得るもの」と推察された 最近の研究によれば陰極よりある程度離しておけば腐蝕 溶解が少ないという人も市る。

以上は主として庄司務氏が「大戰中の電氣化学」(昭21) に発表せられたるので, それよりすでに七星霜が経過し， この間高分子の化学と工業は全く面目を新たにした。す なわち輸入國座品の量座による價格の低廉化と品質の向 上は目ざましいものがあり，一方テフロン，マーカイト， シリコン樹脂等々目新しい材料が合成せられた。現在再 び高分子材料隔膜の改良試驗を行うべき時期が來ている のではないかと思われる。その 1 として最近発表せられ た高分子隔膜をその特許公告 ${ }^{44)}$ により述べてみよう。 これはメタクリル酸メチルエステル重合体, メタクリル 酸エチルェステル重合体及びその共重合物起纎維狀, 粉 末狀などになして次のような狀態で隔膜に使用するので 安る。

(イ）纎 維

重合体の纎維は他の粉末物質, 例えば硫酸バリウムな どと揑和して糊狀物となして種々の隔膜材質に塗布して 隔膜を構成せしめる。

(口) 織 布

硝子瀻維のごとく重合体だけで織布となし沪過性隔膜 として用いる。

(八) 粉 末

種々の粒度のものを調製して柾密を自由に变更し用い る。

\section{（二）粉末熔融板}

重合体の粒度及びその配合法・熔融溫度を变えて氣孔 径・有孔率・透過率・電氣抵抗の種々異った多孔板を製 作し硬質隔膜とする。

さらに成形手段の 1 例を挙げると次の通りである。す なわ台例之ば経緯 $16^{\prime} \mathrm{S} / 2 \mathrm{~S}$, 撚密度 $14 / \mathrm{cm}$ 綾織の織布 を支持材としてこれに 2〜6d長さ $0.5 〜 10 \mathrm{~mm}$ の重合 物短繊維と 100 300 メッシュの重合物粒子を，例えば重 量比 1:1 または 1:2にて混合したものを $3 \sim 9 \mathrm{~g} / \mathrm{dm}^{2}$ 


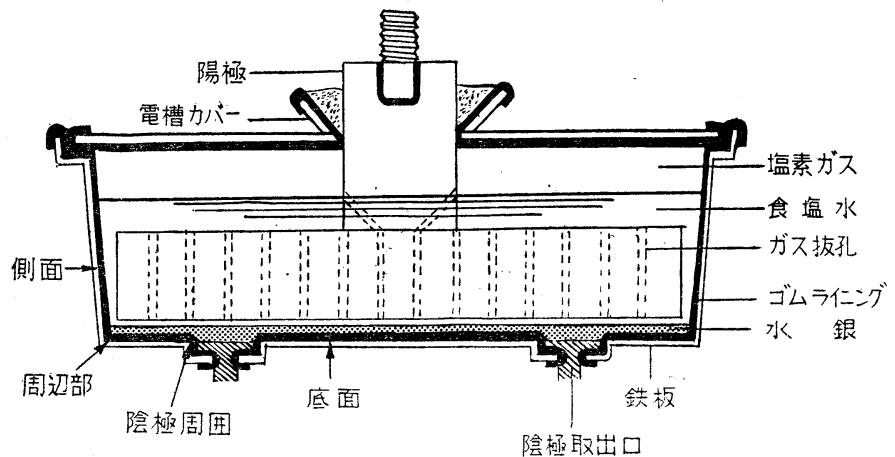

第 2 圖

の密度に充塤して隔膜を形成する。

耐蝕性に関する比較実驗例を表示すれば第》5 表の通り

である(数值は $1 \mathrm{~m}^{2}$ が $100 \mathrm{hr}$ の電解によって侵蝕せ られた量をgであらわした）

\section{第 5 表}

\begin{tabular}{|c|c|c|c|}
\hline 膈 膜 材 質 & $\mathrm{Na}_{2} \mathrm{SO}_{4}$ 電解 & $\begin{array}{l}\text { アルカリ } \\
\text { 性水電解 }\end{array}$ & $\begin{array}{l}\text { 酸 性; } \\
\text { 水電解 }\end{array}$ \\
\hline 綿 織 布 & 全 部溶解 & 0.0653 & 1.563 \\
\hline 子 織 布 & 0.1077 & 2.140 & 0.0685 \\
\hline $\begin{array}{l}\text { ダクリル酸 } \\
\text { チル重合体織布 }\end{array}$ & 0.0051 & 0.017 & 0.0064 \\
\hline & 0.321 & 0.650 & 0.0929 \\
\hline & 0.018 & 0.0192 & 0.0323 \\
\hline & 0.410 & 0.227 & 0.294 \\
\hline
\end{tabular}

透過率, 電氯抵抗の 1 例を挙げると塩化アルカリまた は芒硝電解の場合ではメタクリル酸メチルェステル重合 体織布で, 電圧降下 $0.2 V$ (石綿を用いる場合 $0.15 \sim 0.2 V$ ) でめる。な拈同公告によれば芒确電解として用いれば該 電解最大の湓路たる隔膜問題を一挙に解決して成功に導 くという。筆者らは局外者であるがその工業的成功を新 るものである。

(B) 沪布, 作業衣

ここで沪布として挙げるのは食塩精製作業中の沈澱の 沪過用でまる。すなわち原監を水または電槽上り出た稀 薄䩎水で溶解してその中の $\mathrm{Mg}^{++} \mathrm{Ca}^{++}, \mathrm{SO}_{4}=$ を除去す るため $\mathrm{NaOH}, \mathrm{Na}_{2} \mathrm{CO}_{3}, \mathrm{CaCl}_{2}$ (または $\mathrm{Ca}(\mathrm{OH})_{2}$, $\mathrm{Na}_{2} \mathrm{CO}_{3}, \mathrm{CaCl}_{3}$ ) を加えて次の反隼に上り生成した沈潵 を夜と分離するのである。

$$
\left.\begin{array}{c}
\mathrm{MgCl}_{2}+2 \mathrm{NaOH}=\mathrm{Mg}(\mathrm{OH})_{2} \downarrow+2 \mathrm{NaCl} \\
\mathrm{CaSO}_{4}+\mathrm{Na}_{2} \mathrm{CO}_{3}=\mathrm{CaCO}_{3} \downarrow+\mathrm{Na}_{2} \mathrm{SO}_{4} \\
\mathrm{Na}_{2} \mathrm{SO}_{4}+\mathrm{CaCl}_{2}=\mathrm{CaSO}_{4} \downarrow+2 \mathrm{NaCl}
\end{array}\right\}
$$

$\mathrm{NaOH}, \mathrm{Na}_{2} \mathrm{CO}_{3}$ は反應を完結せしめるため約 5 10\% 過剩に加えるから夜は弱アルカリ（pH=9～10）であり， さらに水銀法では $\mathrm{NaClO}, \mathrm{Cl}_{2}$ などを僅かながら含むか ら葛城布乞の他木棉繊維の沪布としての壽命は短かく塩 化ビニリデン等が期待される。ただし圧派機を用いる関
係上良質のものを 用いないと逆効果 になることに注意 を要する(第 5 表 C 工場）第 5 表卧等 者が個人的に聽取 したデータを䌆め たものである。

作業衣について もさらに良好な成 績が挙げられてお り特に圙粉作業を 行う労務者の衣料事情は著し く改善されている。

\section{2. ライニンダ}

前述の通りわれわれの仕事 は畫夜の別なき腐蝕との鬪い でまって强度・耐蝕性・價格 の点よりライニングは强力な

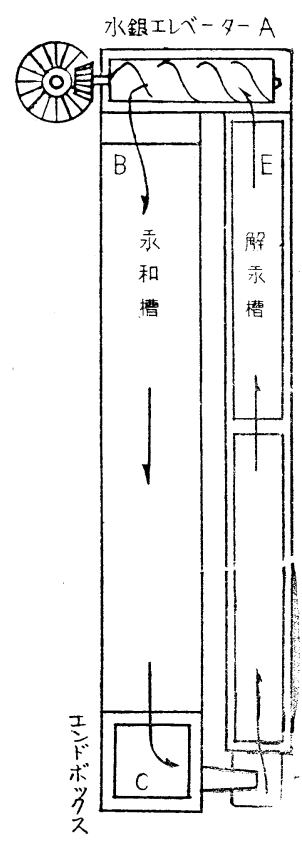

第 3 圖 武器である。以下例として水銀法電槽について述べるこ とにしよう。第 2 図は改良型クレブス式水銀槽の構造を 示したもので第 3 図は水銀の動き方を示す。すなわち $\mathrm{A}$ 部に入れられた水銀はポンプにて B 部にくみ上げられ傾 斜のついた录和槽を B から C 亿流れ解采槽に入り Dょ り Eへ流れ Aにるどって再び循還する。この間行われる 反應は BC 間では

$$
\begin{aligned}
& \mathrm{Na}^{+}+\Theta \longrightarrow \mathrm{Na} \stackrel{+4 \mathrm{Hg}}{\longrightarrow} \mathrm{NaHg}_{4} \\
& \mathrm{Cl}^{-}+\oplus \longrightarrow \mathrm{Cl} \longrightarrow \frac{1}{2} \mathrm{Cl}_{2} \uparrow
\end{aligned}
$$

また DE 間では次の反應が起る

$$
\mathrm{NaHg}_{4}+\mathrm{H}_{2} \mathrm{O} \longrightarrow \mathrm{NaOH}+4 \mathrm{Hg}+\frac{1}{2} \mathrm{H}_{2} \uparrow
$$

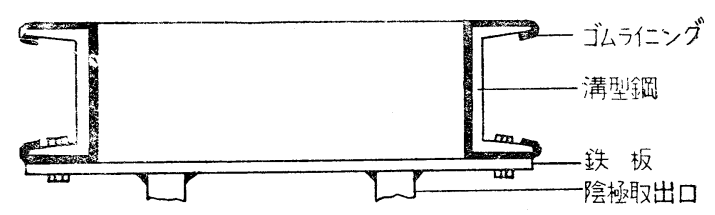

第 4 圖

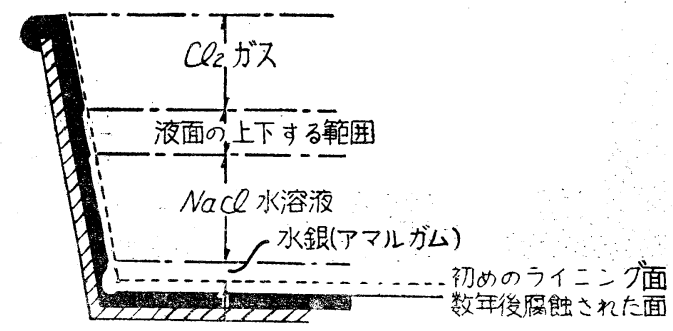

笴 5 畗 
第 6 表

\begin{tabular}{|c|c|c|c|c|c|}
\hline 工 & 場 名 & A & B & $\mathrm{C}$ & D \\
\hline \multirow{2}{*}{ 噚 命 } & 葛城布 & 30 日 & 14日 & 30日 & 23日 \\
\hline & ビニル布 & 123日 & 39日 & 7日 & 37 日 \\
\hline
\end{tabular}

食塩水は B上り飽和（300～310 G/L) NaCl で注入され $(200 \sim 270 \mathrm{G} / \mathrm{L}) \mathrm{NaCl}$ 迄電解されて Cより排出される。 $\mathrm{C}$ 上り D に移るときの水銀中の $\mathrm{Na}$ は $0.05 \sim 0.2 \%$ 程度, E では分解を受けて Na を含まない。Bより注入されあ るいは排出される食塩水 (以下注入塩水・返揆塩水々呼 ぶ）の組成を示せば第 7表のごとくである。

第 7 . 表

\begin{tabular}{|c|c|c|}
\hline & 注 入塩 水 & 返䢪塩 水 \\
\hline $\mathrm{NaCl}$ & $298.6 \mathrm{~g} / 1$ & $250.0 \mathrm{~g} / \mathrm{l}$ \\
\hline $\mathrm{NaClO}_{3}$ & 13.6 & 14.7 \\
\hline $\mathrm{Na}_{2} \mathrm{SO}_{4}$ & 15.0 & 15.4 \\
\hline $\mathrm{NaClO}$ & 1.1 & 0.5 \\
\hline $\mathrm{Cl}_{2}$ & 0.2 & 0.8 \\
\hline $\mathrm{Mg}$ & 痕跡 & 痕 跡 \\
\hline $\mathrm{Ca}$ & 0.01 & 0.01 \\
\hline $\mathrm{Fe}$ & $\longrightarrow$ & 痕 跡 \\
\hline
\end{tabular}

注入塩水の純度は特に混じ易いアルカリ土金属及び重金 属について嚴密を要し, かかる金属の存在は電解反憵中 水銀の表面に電析して水素過電圧の異狀低下を來し運轉 を不能ならしめる(19, 20) 例穴ば Mnvi 及び MnviI は 10-6 でも大きな害を與え $10^{-4} \sim 10^{-5}$ 程度混入されると電解 はほとんぞ不可能になる。この場合は $\mathrm{Cl}_{2}$ ガスの中に $\mathrm{H}_{2}$ ガスが混入して來て甚しいときは爆発を起す。 $\mathrm{Cr}$, $\mathrm{V}$ なども同樣でこのため不銹鋼その他は電解作業に禁忌

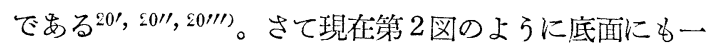
面に施す場合と第 4 図のよ弓に側面にのみに施工して底 面には行わない方法がある, 某工場の硬質ゴム張り電解 槽の腐蝕狀況を見ると第 5 図のごとく水銀またはアマル ガムの鹰蝕が最も大きいようであり次に食塩水で（その 組成は返送塩水に近い)塩素ガスの简創は殆えどない。 このことは腐蝕が水銀またはアマルガムによることを示 し，その理由は次のごときことが考えられる。

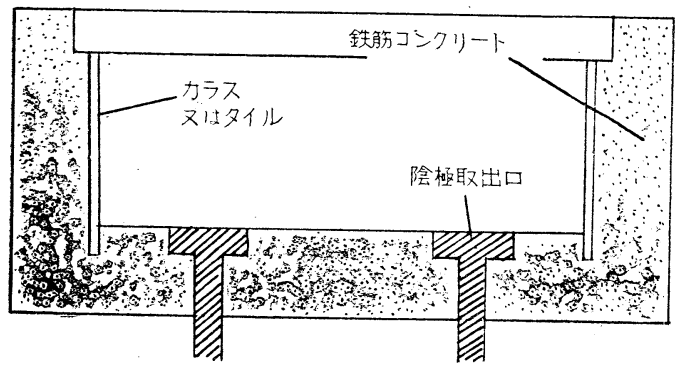

第 6 圖
1. 强アルカリ性であること

2. 還元性が强いこと

3. 比重が大きいから機械的摩粍を起す可能性が大き いこと

4. 食監水と反覀して濃厚苛性ンーダを部分的に生じ, また場合によってほ食塩の結晶を生成する。その際発熱 し水素の泡を出すこと

また塩素による腐蝕があまりないのに液に浸っている ところに笍蝕が起っているのは $\mathrm{ClO}^{-}$の腐蝕力が大きい ことを示し部分的に $100^{\circ} \mathrm{C}$ 近い高䓡になることと共に 電槽ライニングにとって重要な示唆である。このため例 えばネオプレンは余り期待できない。次に数年の使用で 摩粍か起った場所ば次のごとくであった。

第 8 表 (第 2 図参照)

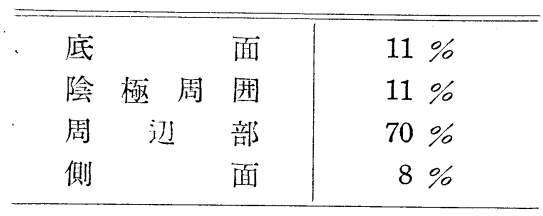

また噟蝕によらないものでも接着不十分のためゴムと

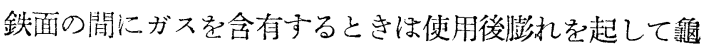
裂を生じ，その龜裂（めるいははじめから存在するピン ホールと共に）から入ったイオンはさらに金属を侵蝕し てガスを発生するため㝥れはさらに霄大する。不完全な 接着とピンホールほ最子恐ろしい。

最近某社で行った工業化試臉電慒のゴムライニングひ 数䉪月にして一部鼠裂を生じたと入聞する。味の素川崎

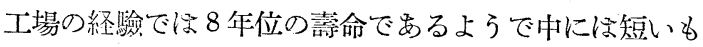
のも㐫が加工の方法を改善すれば 10 年以上でも容易 でまるように思う。現在のッーダ工場では殆んど第 6 図 のようなコンクリート槽を用いて扔り，このため次のよ らな不利がある。

1. 帚命が短かいこと

2. 底面が上述のように水銀または食塩水のために篇

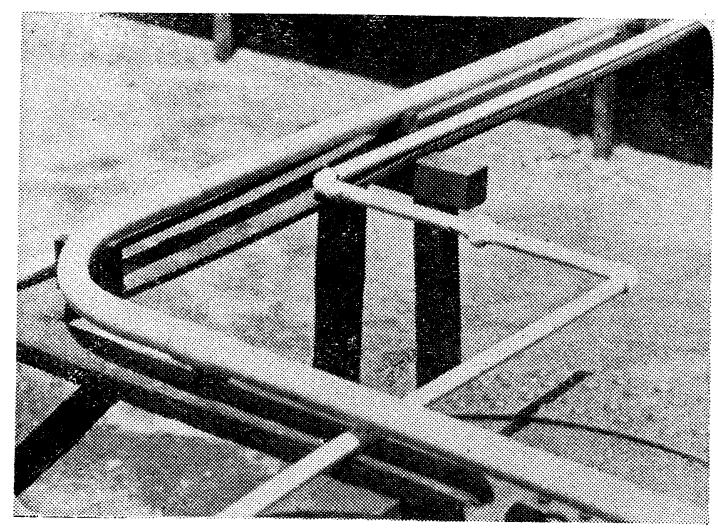

硬質塩化ビニル管の使用狀况 (太い方が塩酸, 細い方は 圧縮空氣用である, 塩酸用は長、区間に瓦って, 継目の ないととに注意)（果㗏合成株式会社名古屋工場） 
蝕を受けいわゆる「荒机」てくるため水銀を一面にうす く流す機能を失うこと

3. 面の腐蝕によって水銀または食塩水を污染して円 滑な作業を妨げること（例えば $\mathrm{Al} \cdot \mathrm{Ca}$ の溶出）

4. コンクリート面の小孔や㦯裂から水銀が侵入する こと

殊に最後の点はなかなか厄介な問題で一度水銀の侵入 があるとアマルガムはコンクリートを腐蝕して龜裂を深 め逐に漏洩するに至るのみならず一度浸潤分散した水銀 は回收が困難でその一部は必ず損失になる。水銀の價格 は t 200 250 万円であるから会社工場の莫大な損失に なるがそれの久ならずまた相当量を錸入に賴っているわ が國の現狀から國家的にゆるがせにできない問題である 录和槽のライニングとして具備すべき條件として次の ようにいえると思う。

1. $\mathrm{Na}-$ アマルガム (隔膜法でほ $\mathrm{NaCl}$ を含を $\mathrm{NaOH}$ 液一陰極液) 及び $\mathrm{NaClO}$ を含む $\mathrm{NaCl}$ 液 (隔膜法では陽 極液), 濕閵 $\mathrm{Cl}_{2}$ ガスに耐えること

2. 仕上面は平滑であって例えば $0.04 \sim 0.1 \mathrm{~m} / \mathrm{m}$ 以上 の山凸，ことにねじれなどがないこと位，使用中にるこ れ以上の変形などがないこと

3. 常溫 $50 \sim 70^{\circ} \mathrm{C}$, 部分的には $80 \sim 90^{\circ} \mathrm{C}$ に及ぶこ とがあるからこの程度の耐熱性を有すること

4. 重金属 ( $\mathrm{Cr}, \mathrm{Mn}, \mathrm{V}, \mathrm{Ti}$ など) を含委ねこと

5. でき得ればセメントーる施工可能であること，ま

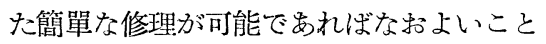

電槽は現在多くセメント製であることは前述の通りで あるからこれにこのまま被覆できるゴムまたは樹脂があ れば甚だ有難い。これはつぎの理由によるものである。

a. 設備費が廉くてすむこと

b. 從って將來の改造などのとき便宜であること

c. 万すい鉄板は加工中または使用中往々にして歪及 やよじれを生じ易いこと（鑄鉄に加工す机ば完全である が高價である)

d. ゴム張りより保溫性が大きいこと

すでに欧米では天然または合成ゴムで実施しているよ らである。外に煉瓦及び木材に対するゴムライニングも 行われている22, 23) 次に P. B. ${ }^{45)}$ に上り戰後 “堅型迥轉 陰極水銀電解慒”としてわが國でも注目の的となった Rotating Cathode Mercury Cell の施設せられていた Hüls の I. G. の工場に括けるゴムライニングについて 述べる。当工場ではゴム張りの仕方が惡かったので修理 が多かったという。戰時中だったため天然ゴムは用いら れず各種の合成ゴムが用いられその㷼命は 3 䈯月から 3 年位，平均 18 籣月であった。これに対し天然ゴムは 7〜8 年聞である。I. G. の自家製合成ゴムほいろいろ試 驗した結果次のるのがよかったようで岕る。

ブナ 85 (no styrene) 100 分
ポリ塩化ビニル
30 分
硫带
$25 "$

これに dibenzol thiocyl disulphide (Vulkacite) を加 える。これは加㧧促進剤策充填剂である。ここでは開戰 後数箇月塩化ビニル重合物の不足からよいと知りつつこ の処方を用いることができなかったという。破損した電 解槽が小部分であ机ばその場で電氣加硫器を使いパッチ を当てることもあるが文の壽命は非常に短い由である。 それはパッチの加硫がそこに残っている古いゴムを傷め るのである。一般に修理するときはゴムを燃して虽ぎ取 る。このとき鉄部に歪みが起るがこれは機械で剻る。ゴ ム張りする前にサンドブラストで異物を取り除きブナ $S$ と酸化亞鉛のベンゼン溶夜を直台に塗り酎いた面が酸化 するのを防ぐ，これを 6 時間乾燥する。次にブナ $S$ ，べ ンゼン及び Coresin と呼ぶ樹脂でできたゴムせメント を筀る。そして約 3 時間榦燥する。さらに数回これを繰 返してゴム張りができ上る。ライニングの厚みは 6〜10 mmである。空氣を拢くため注意深くシートに成型した 後高圧スパークで試驗し玻がなければ鋼鉄の加硫器で 3 氣压の蒸氣を用い 3 時間牛加硫する。製品の硬度は 90 〜95 (ショアー) である。筆者の考えるに天然ゴムの方 が壽命が永いといら報告は有効なアドバイスとして受取 るべきでその壽命が 7 8 年といらのも正鴾を得ている というべきであろう。

以上は電解槽のみについて述べたが, 酎酸, 耐アルカリ ライニングに対する姴望は電解ソーダ工業全般（塩酸・ 唒粉・液体塩睃及び他の锰化物製造裝置を含む）に互つ て强い。電解ソーダ工業で取り技う物質を大別すれば次 のごときものである。

食塩水 $\left(\mathrm{ClO}^{-}, \mathrm{ClO}_{3}{ }^{-}, \mathrm{SO}_{4}=\right.$ などを含を $)$

陰極液 $\left(\mathrm{NaOH}, \mathrm{NaClO}_{3}^{-}, \mathrm{NaCl}\right.$ 含含 $)$

塩素ガス (乾及び濕)

水素ガス（微量の $\mathrm{Hg}$ を含むことあり）

塩酸ガス (残存 $\mathrm{Cl}$ を含むことあり)

塩酸（微量の $\mathrm{Cl}$ 有機物を含むことあり）

晒粉・唒液 $(\mathrm{NaClO}$ 溶夜・ $\mathrm{NaOH}$ 共存 $)$

液体塩素 (稀に微量の水分・ $\mathrm{CO}_{2}$ など混入)

その他硫酸 (Cl を含む) アンモニアなど

これらの対象に対して実驗室で耐久性专りと認められ た材料が現場に和いて往々にして腐蝕せられるのはそれ 以外の微量混入物質の腐蝕が大きいからであって例えば 食塩水でほ $\mathrm{ClO}^{-}$, 水素ガスでは微量の $\mathrm{Hg}$, 塩酸では $\mathrm{Cl}$ または微量の有機物のごとくで徍々にして大失敗を する。例えば純 $\mathrm{HCl}$ の久では数年の使用に異常のなかっ たゴム張塩酸用タンクが有機合成よりの回收塩酸が混入 し，その中の微量のクロラールまたは四塩化炭素のため 数旬にして使用に耐えない程度に損傷した例がある。他 に一例として電槽より排出される返暌塩水について述べ 
ると $\mathrm{Cl}_{2}, \mathrm{ClO}^{-}, \mathrm{ClO}_{3}$-などのため塩水調製の機械裝置の 損楀が甚だしいので現在次のごとき対策が考えられる。

1. $\mathrm{NaOH}$ を加えて中和する方法

2. 酸化性物質を除去する方法

3. 耐蝕性の裝犆を使用する方法

第 1 法は $\mathrm{NaClO}$ が战存するので完全でなく第 2 法に は返揆篮水を $\mathrm{pH}=2$ になるをで $\mathrm{HCl}$ を加えこれを絕 対圧 $360 \mathrm{~m} / \mathrm{m}$ 位のタンクにフラッシュし，処理前の 0.4 $\mathrm{g} / 1$ の $\mathrm{Cl}_{2}$ \% $0.09 \mathrm{~g} / 1$ 位迄減らし次にこれに空氣を通じ 残ガスを追出す锢空法 ${ }^{24,25)}$ と返迻塩水をアルカリ性と 乙黑鉆曆を通じ次の反應を行わしめる炭素分解法 5 , 26) がある。

$$
2 \mathrm{NaClO}+\mathrm{C} \longrightarrow \mathrm{NaCl}+\mathrm{CO}_{2} \uparrow
$$

いずれにしても裝置と労力と動力と製品の一部を消費

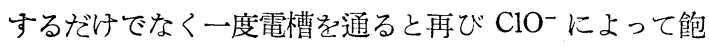
和されるのであるから環境衞生と沈澱沈降の促進（原塩 中の $\mathrm{Mg}^{\prime \prime} ， \mathrm{Ca}^{\prime \prime}$ を沈激として分離するとき $\mathrm{NaClO}$ が 出ると謬質化学的に沈降を防害する）などの利点を除け ば完全な方法とはいえない。ここで第 3 法との経済的優 劣が論ぜられよいライニングが渴望されるのである。最 近硬質ゴムの外に Neoplene, Saran, Tefron の耐蝕材料 ができつつあり，すでに東亞合成その他の会社での國痤 化子進及气の成果が待たれる。しかしわれわれが出現を 待望しているのは酸にも負けずアルカリにる負けずまた 酸化性イオンにも負けずしかるかなりの附熱性（最高80

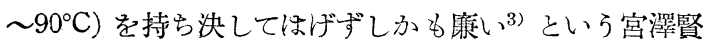
治ばりの悲願であるから問題はそう簡單ではなさそうな 氣がする。一般無機及び有機工業藥品に対する金属・樹 脂及びゴムなどの附蝕性についてほ Perry のよい集錄 がある(7)。(味の素株式会社研究室)

\section{文献}

1) 松野: 工業物理化学, 第 2 輯 107 頁 (昭 23)

2) 田代, 歓崎：電解隔膜, (化学肥料叢書 15) (昭 24)

3) 松野: 電化, 9720 (昭 27)

4) 龜山：麗氣化学の理倫及應用 (下卷), 475 頁 (昭 5)

5) U. S. P. 855,221 (1907)

6) Stuart, Lyster \& Murray : chem. Met. Eng. 354, 45 (1938)

7) 麗解隔脱委員会：霓化, 40118 (昭 25)

8) Förster: Electro chemie Wässeriger Lösungne 99 (1923)
9) Hooher: Trans. Am. Inst. Chem. Eng. 5513 (1920)

10) 向坊：電氣化学大会第 19 回大会にて講演 (昭 27)

11) 龜山：電氣化学の理倫及應用 (下卷) 494 頁 (昭 5)

12) 向坊: ソーダと塩素, 34 第 11,12 号 2 (昭 26) 及び麗氣 化学秋季大会にて講演 (昭 26)

13) Allmand: Applied Elestrochemistry 159 頁 (1932)

14) Stender. Jornitsky \& Sago: Am. Electrochem. Soc. 565 71 (1935)

15) 眞田; 工化 62547 (昭 14)

16) Stender: Am. Electrochem. Soc. 5167 (1935)

17) 牛沢氏談 (日本ソーダ工業会)

18) 庄司：電化 1613 (昭 20)

19) 岡田: ソーダと程素 7 第 1 号 1 (昭 25)

20) 吉沢: 工化 9051 (昭 23) 184, 23452 (昭 24)

20') G. Angel \& T. Lundén : J. Electrohem. Soc. 99435 (1952)

$\left.20^{\prime \prime}\right)$ G. Angel \& Brännland: " 99442 (1952)

$\left.20^{\prime \prime \prime}\right)$ G. Angel, T. Lundén \& R.Brännland : " 10039 (1953)

21) 柇野: 電化 49520 (昭 27)

22) Chem. Trade. J. 38125 (1949)

23) Chem. Trade. J. 1137129 (1951)

24) Fiat Final Report No. 816 p. 62

25) Fiat Final Report No. 732 p. 14

26) Tnat Final Report No. 834 p. 8

27) Perry: Chemical Engineers' Handbook (Text. ed) p. 1461

28) 中川：ソーダと塩素, 10 第 3 号 3 (昭 27)

29) Blaw-knox Construction Co. : Bulletin No. 2261

30) Gardiner: Chem. Eng. 62011 (1947)

31) Fiat Final Report No. 431, 732 その他

32）味の素交び東洋カーボン株式会社：実用新案出願 昭 27-3646

33) 庄司：電化, 2113 (炤 20)

34) 日本ソーダ工業会技術委員会：電極分科会議事錄

35) Joffe: Z. Elektrochem. 7142 (1936)

36) Chem. Week. Jan-5 (1952) Chem. Trade. J. 272130 (1952)

37) 例えば旭㗂子株式会社：特許出願 昭 26-6712

38) 例えば添田,佐原：電氣化学大会第 19 回大会にて講演 (昭27)

36) 例えば Life 1 No. 13 (1950)

40) 電氣化学協会電解隔膜委員会：電化 53320 (昭 27)

41) 膽次：日本アスベスト時㪕 9,6 (昭 27)

42) 向坊: 雪化 48220 (昭 27)

43) 松野: 䇩化 52020 (昭 27)

44) 三菱レイヨン株式会社: 特許出願公告 昭 27-3216

45) Fiat Final Report No. 817

46）田中：日本アスペスト時報 16,6（昭 27）

47) 米村: 味の素技術資料 No. 99 (昭 27)

48) 仲森, 金井：6873 (昭 27 )

49) Du. Pont. Plastics-Polyethylene (Catalogue)

\section{会員の皆樣へ 正会員一括加入の件}

最近，各大学，会社研究所，工場で「高分子」及び高 分子研究論交集を敉材に用いている所が，一括加入でき ないかと問い合せがあります。

この制度は，すでに以前からめりますので，5 人以上
会員のまとまつた所で,誰か責任者をきめて戴いて，1篁 月または 2 䈏月分の会費をまとめて揆って戴けば，牛年 または 1 简年の会費を挆䢪り戴けなくとも，会誌はその 責任者宛に御逵付申し上げますからこの制度を活用し， 一括申込みをして戴きたいと存じます。 